\title{
METABOLIC CHANGES IN THE BLASTOCYSTS OF MICE AND RATS DURING DELAYED IMPLANTATION
}

\author{
H. M. WEITLAUF* \\ Departments of Anatomy and Gynecology and Obstetrics, \\ University of Kansas Medical Center, Kansas City, Kansas 66103, U.S.A.
}

The duration of the preimplantation period is not rigidly fixed in mice and rats. Although attachment of embryos to the uterine epithelium normally occurs late on the 5th day after fertilization, it may be delayed for days or weeks by concurrent lactation (naturally delayed implantation) or maternal ovariectomy (experimentally delayed implantation). It has long been known that the development of such 'delayed implanting' embryos is arrested at the blastocyst stage, and it has recently been shown that their overall embryonic metabolism is reduced. This depressed metabolic rate may be related to the ability of embryos to survive the prolonged free-living phase associated with delayed implantation.

How delayed implanting embryos are rendered metabolically dormant and then reactivated to implant at a later time is unknown. However, a comparison of changes in the rates of protein synthesis and $\mathrm{CO}_{2}$ production in normal and delayed implanting embryos under various experimental conditions provides some clues to this mechanism and establishes a basis for further experimentation.

\section{PROTEIN SYNTHESIS}

The level of protein synthesis in mouse embryos before implantation has been estimated from the incorporation of labelled amino acids. Unfortunately, the results based on experiments in vivo or in vitro are conflicting and there is, therefore, controversy on the extent of protein synthesis in early embryos.

Labelled amino acids injected into mice at specific times during the preimplantation period are readily incorporated by blastocysts in the uterus but not during cleavage in the oviducts (Greenwald \& Everett, 1959; Weitlauf \& Greenwald, 1965; Glass \& Hanson, 1969). This suggests that little or no protein synthesis occurs in mouse embryos prior to blastocyst formation. On the other hand, it has also been reported that mouse embryos cultured in vitro incorporate labelled amino acids as early as the two-cell stage and show increasing incorporation after the eight-cell stage (Mintz, 1964; Monesi \& Salfi, 1967; Monesi, Molinaro, Spalletta \& Davoli, 1970; Tasca \& Hillman, 1970; Brinster, 1971). Furthermore, puromycin blocks development of two- and eight-cell embryos in vitro (Thomson \& Biggers, 1966). These observations

* Present address: Department of Anatomy, University of Oregon Medical School, Portland, Oregon 97201, U.S.A 
suggest that preimplantation mouse embryos synthesize protein throughout the early stages, with marked increases occurring in the morula and blastocyst.

Failure to detect significant protein synthesis by cleaving embryos in vivo (i.e. a false negative result) can result from interference with the tracer by competing pools of endogenous amino acids in the oviducts (as suggested by Mintz, 1965), or by failure of the tracer to equilibrate with endogenous amino acid pools within the embryos. The first possibility was ruled out as follows: blastocysts were recovered from the uteri of normal mice on the 5th day post coitum (p.c.) and transferred to the oviducts of recipients on the 2nd day p.c. When $\left[{ }^{35}\right.$ S $]$ methionine was injected intraperitoneally the transferred blastocysts were heavily labelled while the native two-cell embryos were unlabelled (Weitlauf \& Greenwald, 1967). The possibility that the tracer did not equilibrate with the embryonic amino acid pool was not ruled out by this experiment. The question of net protein synthesis was not resolved until direct measurements of total protein in the embryos were made at various preimplantation stages. With a micro-adaptation of the Lowry method for protein (Lowry,

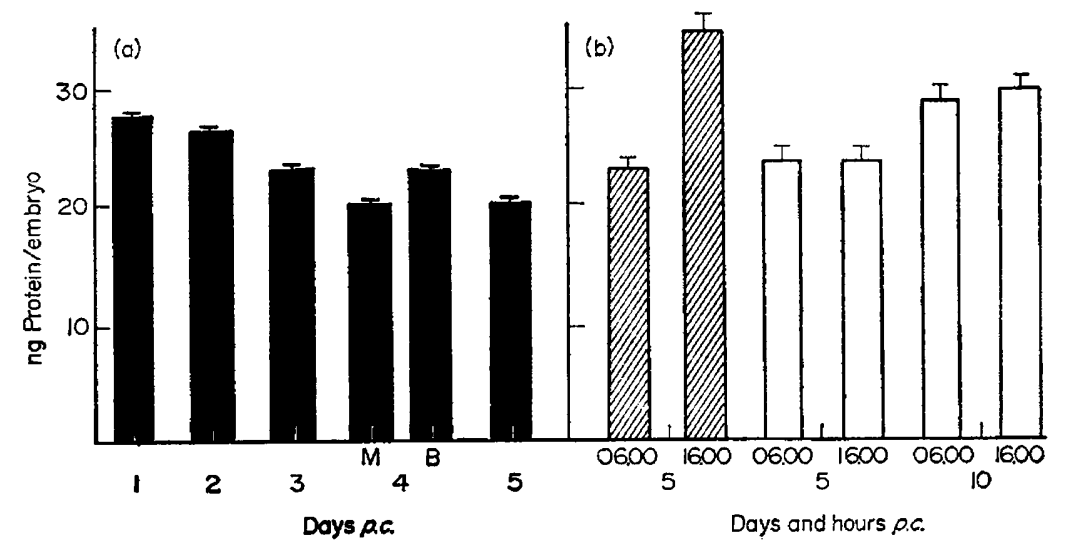

Text-Fig. 1. Protein incorporation in mouse embryos. (a) Normal embryos; $\mathbf{M}=$ morulae, B = early blastocysts. Data from Brinster (1967b). (b) Normal embryos (shaded columns) and 'delayed implanting' embryos (open columns). Data from Weitlauf (1973b).

Rosebrough, Farr \& Randall, 1951), it was shown that total protein content in the mouse embryo decreases by $25 \%$ (i.e. $4 \mathrm{ng} / \mathrm{embryo}$ ) between the onecell and early blastocyst stages (Brinster, 1967b) and increases by $50 \%$ (i.e. $12.3 \mathrm{ng} /$ embryo) in the late blastocysts (Weitlauf, 1973b) (Text-fig. 1).

The conflict between the experiments in vivo and in vitro is more apparent than real and is resolved if incorporation of labelled amino acids by cleaving embryos in vitro primarily reflects the turnover of existing protein and the synthesis of a small amount of a specific protein involved in cleavage, and if the increased incorporation shown after the morula and blastocyst stages in vitro or at the blastocyst stage in vivo reflects the beginning of a marked increase in synthesis and an accumulation of new protein. In any case, it is clear that mouse embryos during 'normal' pregnancy have much higher levels of protein synthesis at the blastocyst stage than at earlier stages. 
In contrast, the level of incorporation of amino acids by embryos in lactational or experimentally delayed implantation is low (Weitlauf \& Greenwald, $1965,1968)$. This suggests that little or no embryonic protein is synthesized in delayed implantation. However, alternative explanations must also be considered.

The possibility that the reduced incorporation by 'delayed implanting' embryos in utero results from selective restriction of amino acids (as suggested by Gwatkin, 1966) or by interference with the tracer by maternal pools of endogenous amino acids was first ruled out. Normal blastocysts recovered on the 5 th day p.c. were transferred to a sterile uterine horn in 'delayed implanting' mice. After the intraperitoneal injection of $\left[{ }^{35} \mathrm{~S}\right]$ methionine, all blastocysts were labelled (Weitlauf, 1969). Therefore, amino acids (at least methionine) are not restricted from the uterine lumen and maternal amino acid pools do not

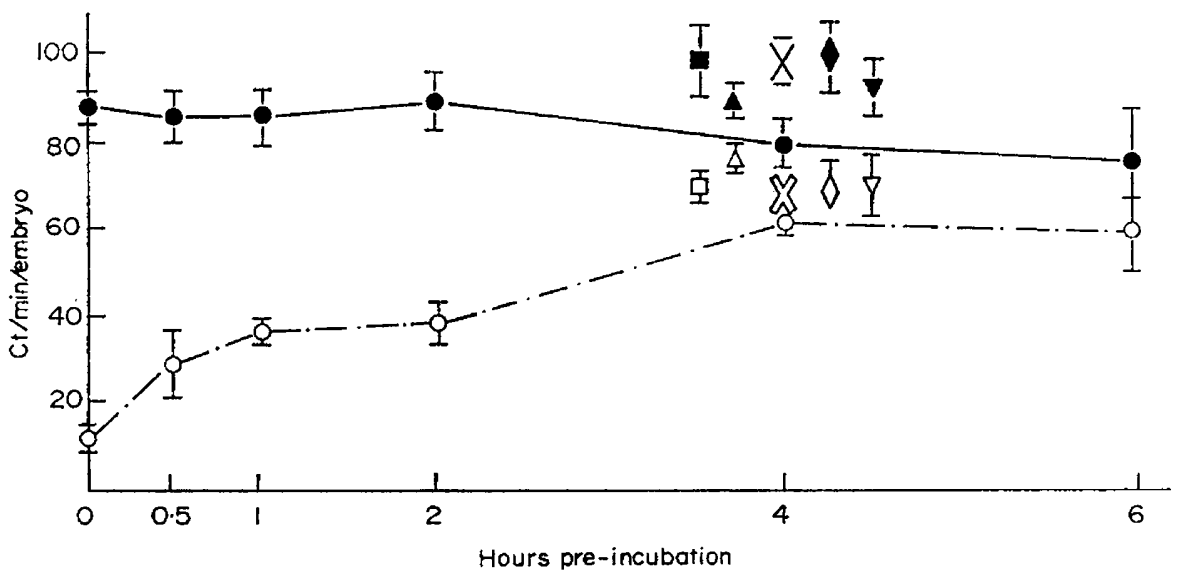

TEXT-FIG. 2. Incorporation of amino acids into acid-insoluble material by blastocysts from intact or ovariectomized mice after various periods of pre-incubation in medium with non-labelled amino acids, and after $4 \mathrm{hr}$ pre-incubation with various steroids. Solid symbols represent blastocysts from normal mice; open symbols represent those from ovariectomized mice. Steroids used in pre-incubation: $\mathrm{a}, 1 \times 10^{-10} \mathrm{M}$-oestradiol$17 \beta ; \Delta, 1 \times 10^{-6} \mathrm{M}$-oestradiol-17 $\beta ; \mathrm{X}$, no hormone; $\diamond, 1 \times 10^{-10} \mathrm{M}$-oestradiol- $17 \beta$ and $\mathrm{I} \times 10^{-7}$ M-progesterone; $\nabla, 1 \times 10^{-7}$ M-progesterone. All values shown \pm one standard error. Data from Weitlauf (1973a).

significantly dilute the tracer. Subsequently, it has been shown by chromatographic methods that the amino acid content of uterine fluid is similar in normal and 'delayed implanting' mice (Gwatkin, 1969). Furthermore, when normal and 'delayed implanting' blastocysts are incubated with the same concentrations of labelled amino acids in vitro, the normal embryos incorporate approximately seven times more label than 'delayed implanting' embryos in the first $30 \mathrm{~min}$ (Weitlauf, 1973a) (Text-fig. 2).

Although these results support the hypothesis that the rate of protein synthesis is low in 'delayed implanting' embryos, the possibility still existed that endogenous pools of embryonic amino acids exclude the tracer and prevent detection of true protein synthesis. Therefore, the total protein content of 'delayed implanting' blastocysts was measured at 06.00 and 16.00 hours on the 5 th or 
10th day p.c. (Weitlauf, 1973b). Normal embryos (on Day 5 p.c.) accumulate approximately $12 \mathrm{ng}$ of protein over a 10 -hr period while the 'delayed implanting' embryos on either the 5th or 10th day accumulate less than $1 \mathrm{ng}$ in a comparable period (Text-fig. 1). Thus, net synthesis of protein occurs in normal embryos (where tracer incorporation is high) and little or none occurs in delayed implanting embryos (where tracer incorporation is low).

Peripheral levels of oestrogen are high at the time of implantation and low during delayed implantation (Whitten, 1955, 1958). This suggests that maternal hormones (particularly oestrogen) are involved in regulating protein synthesis in the embryos. To test this hypothesis, pregnant mice were ovariectomized on the fourth day p.c. and injected with oestrogen and/or progesterone; $\left[{ }^{35} \mathrm{~S}\right]$ methionine was injected intraperitoneally and the embryos were recovered (Weitlauf \& Greenwald, 1968). Following treatment with a combination of oestrogen and progesterone, the blastocysts were labelled, but they were unlabelled after either hormone alone. Egg transfer experiments again demonstrated that the hormones did not act by altering amino acid levels in the uterus.

Although oestrogen and progesterone are involved in the regulation of protein synthesis in the blastocysts, it has not been resolved whether they act directly on the embryos as typical target organs or operate indirectly via the uterus. Therefore, to determine whether or not the hormones act via the uterus, embryos were retained in the oviducts (by a ligature at the utero-tubal junction) of intact or hypophysectomized mice. In this extra-uterine site the embryos develop to the blastocyst stage and have a high level of amino acid incorporation regardless of the hormonal status of the mother. Blastocysts in the contralateral uterine horns of the intact animals also incorporated amino acid, but those in the hypophysectomized animals did not (Weitlauf, 1971). These results seem to support Kirby's (1969) suggestion that oestrogen and progesterone are needed for development only when the embryos are in utero. To establish experimentally delayed implantation in this model, the pituitary was removed. This was done because surgical removal of the ovaries causes scarring of the oviducts and the adhesions make it difficult to recover tubelocked embryos. Unfortunately, small amounts of hormones may still be released from the ovary after hypophysectomy and reach the oviducts. Even though systemic levels of the hormones are inadequate to induce implantation on the contralateral side, it is possible that the tube-locked blastocysts are directly influenced by the hormones. This possibility must be considered even more seriously in view of the report that oestradiol- $17 \beta$ at a very low concentration $\left(1 \times 10^{-10} \mathrm{M}\right)$ increases the incorporation of amino acids by mouse blastocysts in vitro (Smith \& Smith, 1971).

Therefore, normal and 'delayed implanting' embryos were recovered and placed in a modified Brinster's culture medium $\left({ }^{14} \mathrm{C}\right.$ amino acids, leucine, lysine, arginine and valine at $4 \times 10^{-6} \mathrm{M}$ in addition to the ingredients shown in Table 1) for $30 \mathrm{~min}$; acid-insoluble radioactivity was determined with a scintillation counter. The amount of radioactivity in the normal embryos was significantly higher than in the 'delayed implanting' embryos (Text-fig. 2; $0 \mathrm{hr}$ pre-incubation). The experiment was repeated with the exception that the embryos were 'pre-incubated' in medium with non-labelled amino acids 
for various periods up to $6 \mathrm{hr}$ before being placed in the radioactive medium for $30 \mathrm{~min}$. The normal embryos incorporated amino acids at nearly the same rate throughout the experiment. In contrast, the rate of amino acid incorporation for the 'delayed implanting' embryos increased with longer pre-incubation periods (up to $4 \mathrm{hr}$ ) and levelled off at about $75 \%$ of the value for normal embryos.

To test the possibility that the 'delayed implanting' blastocysts require a direct hormonal stimulus to increase protein synthesis to the range of normal embryos, the experiment was repeated except that oestradiol, and/or progesterone, were added to the non-labelled medium (Text-fig. 2). Blastocysts from normal and 'delayed implanting' mice were pre-incubated in the non-labelled medium with steroids for $4 \mathrm{hr}$ before being placed in radioactive medium for $30 \mathrm{~min}$. None of the hormones had any effect on the rate of protein synthesis. Therefore, at least at the concentrations used in this study, it appears that the hormones do not directly stimulate protein synthesis in the embryos.

Although most of the work on protein synthesis in delayed implantation has been done with the mouse, the few experiments performed with rats have

Table 1. Gulture medium

\begin{tabular}{l|c}
\hline \multicolumn{1}{c|}{ Component } & g/litre \\
\hline $\mathrm{NaCl}$ & 6.975 \\
$\mathrm{KCl}$ & 0.356 \\
$\mathrm{CaCl}$ & 0.189 \\
$\mathrm{KH}_{2} \mathrm{PO}_{4}$ & 0.162 \\
$\mathrm{MgSO}_{4} .7 \mathrm{H}_{2} \mathrm{O}$ & 0.294 \\
$\mathrm{NaHCO}_{3}$ & $2 \cdot 106$ \\
$\mathrm{Glucose}_{\text {Bovine serum albumin }}$ & 1.000 \\
Penicillin G (potassium) & 1.000 \\
Streptomycin sulphate & $100 \mathrm{units} / \mathrm{ml}$ \\
& $50 \mu \mathrm{g} / \mathrm{ml}$ \\
\hline
\end{tabular}

yielded similar results. Thus, incorporation of $\left[{ }^{3} \mathrm{H}\right]$ phenylalanine by 'delayed implanting' rat blastocysts is lower than that of normal embryos following intraluminal installation of the tracer; however, the embryos are readily labelled following administration of oestrogen and progesterone (Prasad, Dass $\&$ Mohla, 1968). Similarly, less $\left[{ }^{14} \mathrm{C}\right]$ glutamic acid is incorporated by 'delayed implanting' rat blastocysts than by normal blastocysts in vitro; while embryos recovered 6 to $12 \mathrm{hr}$ after injection of oestrogen and progesterone have relatively high glutamic acid incorporation (Tsujii, Sugawara \& Takeuchi, 1972). Finally, $\left[{ }^{14} \mathrm{C}\right]$ methionine incorporation by 'delayed implanting' rat blastocysts in vitro is less than that of normal embryos in the first 1 to $1 \frac{1}{2} \mathrm{hr}$, but after $1 \frac{1}{2}$ to $2 \mathrm{hr}$ in vitro the level of incorporation increases to nearly normal values (Gulyas \& Daniel, 1969).

In summary, these experiments show that protein synthesis is relatively high in normal mouse and rat blastocysts and that it is low in 'delayed implanting' embryos. Furthermore, it appears that, in utero, oestrogen and progesterone are required to activate protein synthesis but, in vitro or in an extra-uterine site (i.e. the oviduct), the hormones are not necessary. 


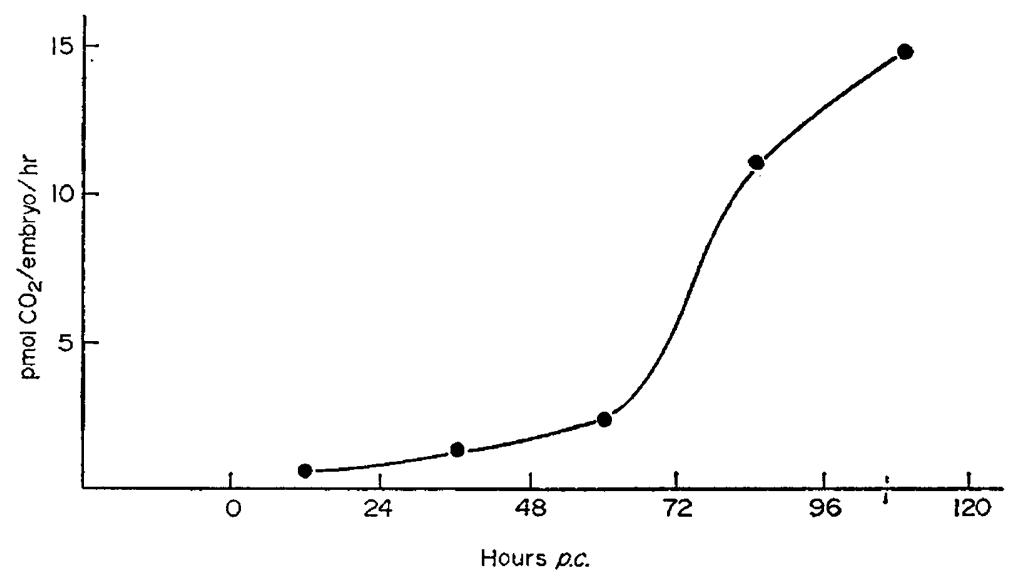

TEXT-FIG. 3. The production of $\mathrm{CO}_{2}$ by developing mouse embryos. Data from Brinster (1967a).

\section{CARBOHYDRATE METABOLISM}

The rate of aerobic metabolism in normal and 'delayed implanting' mouse embryos has been estimated by the production of $\mathrm{CO}_{2}$ in vitro (Brinster, 1967a; Menke \& McLaren, 1970a, b; Menke, 1972). In this procedure embryos are placed in medium containing ${ }^{14} \mathrm{C}$-labelled glucose; ${ }^{14} \mathrm{CO}_{2}$ produced by the embryos is trapped in hyamine hydroxide and measured with a scintillation counter. The total $\mathrm{CO}_{2}$ produced is then calculated to give an estimate of the rate of aerobic metabolism (expressed as $\mathrm{pmol} \mathrm{CO}_{2} / \mathrm{embryo} / \mathrm{hr}$ ). Calculation of total $\mathrm{CO}_{2}$ production from trapped ${ }^{14} \mathrm{CO}_{2}$ assumes that ${ }^{14} \mathrm{GO}_{2}$ is not significantly reduced by $\mathrm{CO}_{2}$ fixation in the embryos, and that $\left[{ }^{14} \mathrm{G}\right]$ glucose

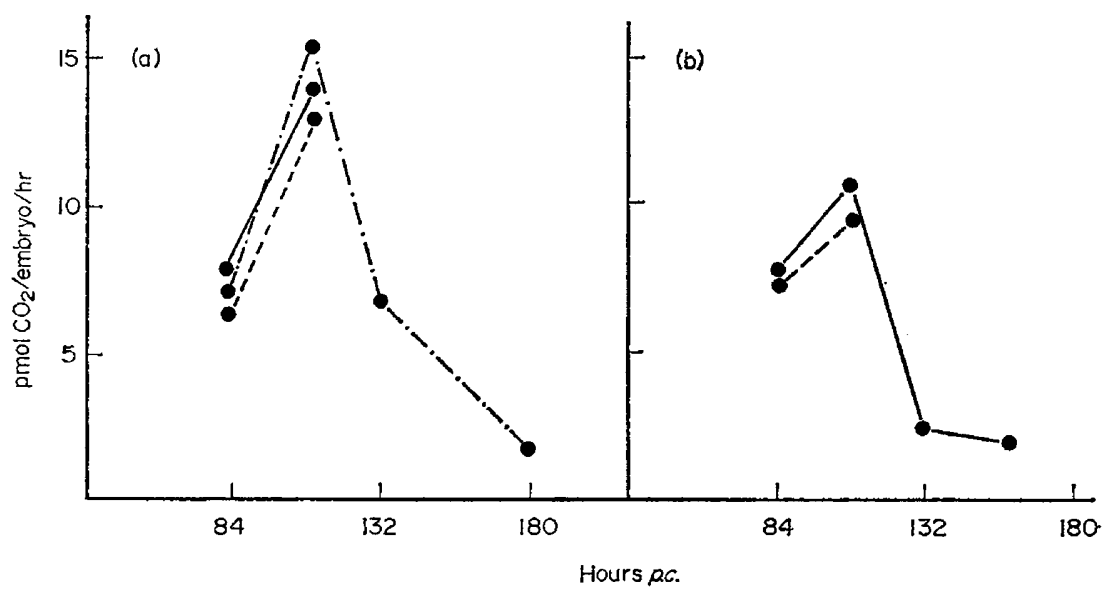

TEXT-FIG. 4. The production of $\mathrm{CO}_{2}$ by mouse embryos from females in various repro-

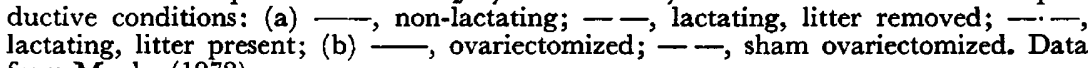
from Menke (1972). 
enters the embryos and equilibrates with endogenous glucose with a resultant specific activity approximately equal to that of tracer in the medium.

The rate of ${ }^{14} \mathrm{CO}_{2}$ production by preimplantation mouse embryos increases at each stage from fertilization through formation of the blastocysts, the greatest increases occurring in the morula and blastocyst (Brinster, 1967a; Menke \& McLaren, 1970b; Text-fig. 3). The fixation of $\mathrm{CO}_{2}$ occurs in preimplantation mouse embryos and is higher in blastocysts than in earlier stages (Graves \& Biggers, 1970; Wales, Quinn \& Murdoch, 1969). Therefore, estimates of increased $\mathrm{CO}_{2}$ production by the blastocysts from ${ }^{14} \mathrm{CO}_{2}$ are conservative. The second point, that ${ }^{14} \mathrm{C}$ glucose enters the embryos and equilibrates with endogenous glucose, has not been completely examined. Glucose enters two- and eight-cell embryos equally well (Wales \& Brinster, 1968) and can be used as an energy source for eight-cell embryos, morulae and blastocysts (Brinster \& Thomson, 1966). The rate of entry for morulae and blastocysts has not been established. However, from what is known about the incorporation of ${ }^{14} \mathrm{C}$ from

Table 2. Effect of oestrogen and progesterone on $\mathrm{CO}_{2}$ production by blastocysts from ovariectomized mice

\begin{tabular}{|c|c|c|c|}
\hline \multirow{2}{*}{ Group } & \multicolumn{2}{|c|}{ Hormone treatment* } & \multirow{2}{*}{$\begin{array}{c}\mathrm{CO}_{2} \text { production } \\
(\text { pmol/embryo/hr } \pm \text { S.E. }\end{array}$} \\
\hline & $\begin{array}{c}\text { Progesterone } \\
(2 \cdot 0 \mathrm{mg} / \text { day })\end{array}$ & $\begin{array}{c}\text { Oestradiol-17 } \beta \\
(0.025 \mu g / \text { day })\end{array}$ & \\
\hline $\begin{array}{l}1 \\
2 \dagger \\
3 \\
4\end{array}$ & $\begin{array}{c}\text { Oil } \\
\text { Days } 7 \text { to } 10 \\
\text { Days } 7 \text { to } 10 \\
\text { None }\end{array}$ & $\begin{array}{c}\text { Oil } \\
\text { Days } 9 \text { to } 10 \\
\text { None } \\
\text { Days } 9 \text { to } 10\end{array}$ & $\begin{array}{l}1.74 \pm 0.22 \\
5 \cdot 17 \pm 0.24 \\
1 \cdot 68 \pm 0.29 \\
1.55 \pm 0.08\end{array}$ \\
\hline
\end{tabular}

* Injections given to the mother subcutaneously in $0.1 \mathrm{ml}$ sesame seed oil on the days p.c. indicated.

$\dagger$ This combination of oestrogen and progesterone induces implantation in ovariectomized mice and, if continued, will maintain pregnancy.

glucose (Brinster, 1969) and the uptake of other sugars (Kramen \& Biggers, 1971 ), it is reasonable to assume that glucose enters the blastocysts more readily than earlier stages. Therefore, estimates of $\mathrm{CO}_{2}$ production by the early stages may also be low. Although these difficulties have not been resolved, the observation that oxygen utilization is higher in blastocysts than in earlier stages (Mills \& Brinster, 1967) appears to confirm the suggestion that the rate of aerobic metabolism in the mouse blastocyst is higher than in earlier stages.

The pattern of ${ }^{14} \mathrm{CO}_{2}$ production by 'delayed implanting' embryos is similar to that of normal blastocysts until the 4th day p.c. but thereafter $\mathrm{CO}_{2}$ production decreases abruptly (Menke \& McLaren, 1970a; Menke, 1972; Text-fig. 4).

The finding that progesterone given to ovariectomized mice still further lowers ${ }^{14} \mathrm{CO}_{2}$ production by 'delayed implanting' blastocysts (Menke \& McLaren, 1970b) suggests that ovarian hormones may be involved in controlling this aspect of metabolism as well as protein synthesis. To test this possibility, mice were ovariectomized on the 4 th day p.c. and given one of several 
hormonal regimens (Torbit \& Weitlauf, 1974) (Table 2). The embryos were recovered on Day 10 and assayed for ${ }^{14} \mathrm{CO}_{2}$ production. The results demonstrate that oestrogen and progesterone are both essential for increased ${ }^{14} \mathrm{CO}_{2}$ production. In a related experiment, it was found that the increase in ${ }^{14} \mathrm{CO}_{2}$ production is not detected until about $20 \mathrm{hr}$ after the injection of oestrogen. In this experiment, the negative influence of progesterone on ${ }^{14} \mathrm{CO}_{2}$ production reported by Menke \& McLaren (1970b) was not observed.

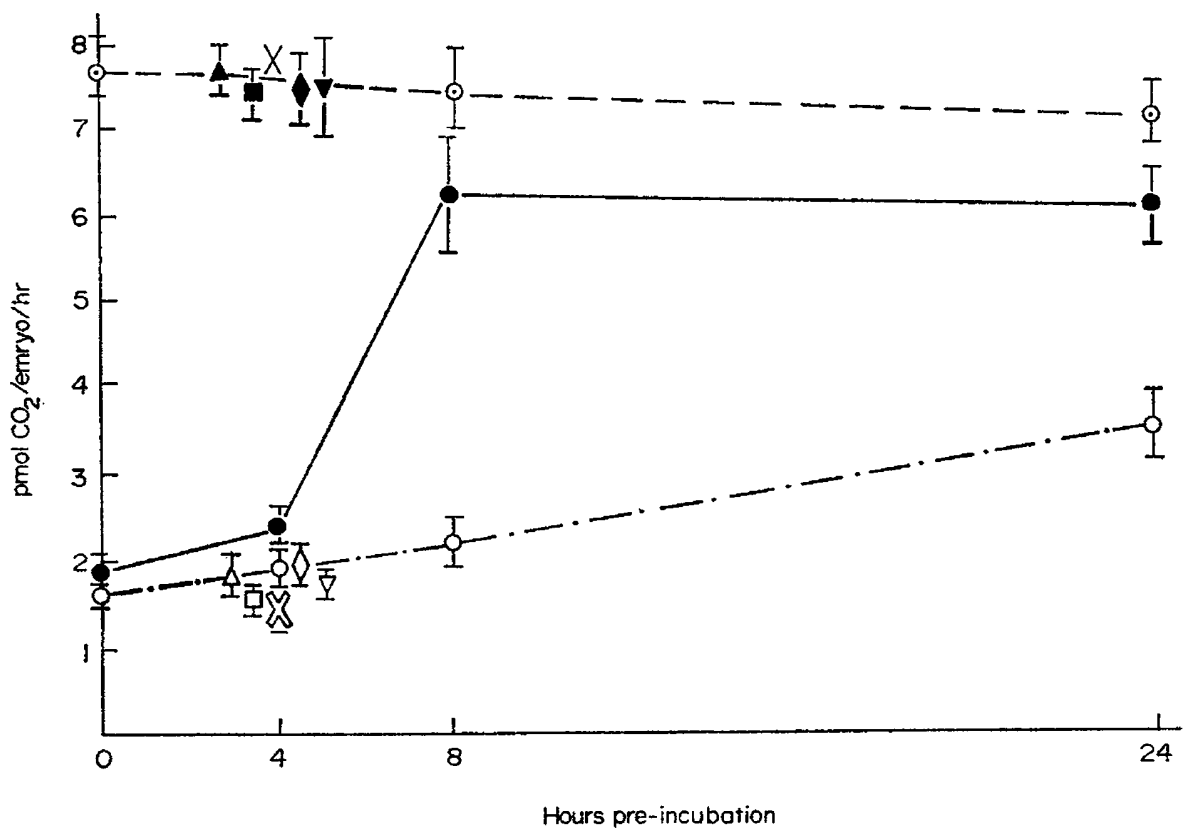

TEXT-FIG. 5. The production of $\mathrm{CO}_{2}$ by mouse blastocysts from $(-\rightarrow)$ intact, $(-)$ ovariectomized oil-treated or $(-\cdot-)$ ovariectomized progesterone-treated animals
after various periods of pre-incubation with non-labelled medium and after $4 \mathrm{hr}$ preincubation with various steroids. Solid symbols represent blastocysts from intact animals; open symbols represent blastocysts from ovariectomized progesterone-treated animals. Steroids used in pre-incubation: $\mathrm{E}, 1 \times 10^{-10} \mathrm{M}$-oestradiol-17 $\beta ; \Delta, 1 \times 10^{-6} \mathrm{M}$-oestradiolI7 $\beta ; X$, no hormone; $\rightarrow, 1 \times 10^{-10}$ M-oestradiol-17 $\beta$ and $1 \times 10^{-7} \mathrm{M}$-progesterone; $\nabla, 1 \times 10^{-7} M$-progesterone. All values are \pm one standard error. Data from Torbit \& Weitlauf (1974).

A series of experiments was then undertaken to test the effects of oestrogen and progesterone in vitro on the rate of ${ }^{14} \mathrm{CO}_{2}$ production by 'delayed implanting' embryos. In a preliminary experiment, normal and 'delayed implanting' embryos were incubated in medium with non-labelled glucose for 4,8 or $24 \mathrm{hr}$, then transferred to medium with uniformly labelled $\left[{ }^{14} \mathrm{C}\right]$ glucose for $2 \mathrm{hr}$ and the ${ }^{14} \mathrm{CO}_{2}$ measured. The normal embryos produced ${ }^{14} \mathrm{CO}_{2}$ at a nearly constant rate throughout the entire experiment (Text-fig. 5). This indicates that the medium was neither stimulatory nor detrimental to the embryos. In contrast, 'delayed implanting' embryos from ovariectomized, oil-treated mothers showed low ${ }^{14} \mathrm{CO}_{2}$ production with 0 or 4 -hr 'pre-incubation' but 
levels near that of the normals at 8 and $24 \mathrm{hr}$. To our surprise, $\mathrm{CO}_{2}$ production by blastocysts from progesterone-treated animals started at the same level as the embryos from oil-treated donors but increased at a slower rate and to a lesser degree. This experiment was then repeated with blastocysts recovered from normal animals or ovariectomized animals given progesterone and preincubated in non-radioactive medium containing oestrogen and/or progesterone (Text-fig. 5) before being transferred to radioactive medium to assay the level of ${ }^{14} \mathrm{CO}_{2}$ production. None of the hormone treatments had any apparent effect on the level of ${ }^{14} \mathrm{CO}_{2}$ production.

The assumption made here, as in the case of the normal embryos, is that ${ }^{14} \mathrm{CO}_{2}$ production is a good measure of total $\mathrm{CO}_{2}$ production and hence provides a reliable estimate of the rate of aerobic metabolism. However, in the case of 'delayed implanting' embryos, nothing is known about the extent of $\mathrm{CO}_{2}$ fixation or, more importantly, about the rate of entry of $\left[{ }^{14} \mathrm{C}\right]$ glucose under the various conditions used in these experiments. Measurements are now being made to compare the entry of $\left[{ }^{14} \mathrm{C}\right]$ glucose into normal and 'delayed implanting' embryos under these conditions.

\section{DISGUSSION}

The marked depression of embryonic metabolism during delayed implantation in mice, and the increased protein synthesis and $\mathrm{CO}_{2}$ production as the embryos prepare to implant are clearly related to the hormonal status of the mother. However, this is only true when the embryos are in utero; in extra-uterine sites or in vitro the metabolic activity of the embryos increases regardless of hormonal conditions, suggesting that the negative influence on embryonic metabolism in delayed implantation is exerted by the uterus rather than by the absence of hormones per se.

There is considerable discussion on how the uterus regulates embryonic metabolism. McLaren (1973) has reviewed the two principal positions, namely that, in the absence of oestrogen and progesterone, the uterus either fails to provide a stimulatory factor essential for blastocyst development or elaborates a substance that is inhibitory to the embryos.

That serum or serum-like substances may be the stimulatory factor is suggested by the following observations: 'delayed implanting' mouse embryos resume proliferation in vitro only in the presence of serum and certain amino acids (Gwatkin, 1966); $\mathrm{CO}_{2}$ production by 'delayed implanting' mouse embryos is increased when serum is added to the medium (Menke \& McLaren, 1970a); and enhanced RNA synthesis by 'delayed implanting' rat blastocysts in vitro occurs in medium containing serum (Psychoyos \& Bitton-Casimiri, 1969). In addition, Hsu (1972) and Hsu \& Baskar (1973) have recently reported that in mouse embryos in culture endoderm and ectoderm are differentiated only in the presence of serum, and they suggest that a specific stimulatory factor is required. For such a mechanism to be involved in regulating embryonic metabolism in delayed implantation, it would be necessary for the uterus to exclude the factor throughout the prolonged preimplantation period and make it available when an appropriate combination of oestrogen and progesterone is provided. 
The most direct evidence that a uterine inhibitor may be involved in depressing blastocyst metabolism in delayed implantation is reported by Psychoyos \& Bitton-Casimiri (1969). A cell-free extract prepared from uteri of ovariectomized progesterone-treated rats was partly purified by column chromatography; a fraction from this extract inhibited RNA synthesis in rat and rabbit blastocysts in vitro. The inhibitory effect was reduced by pretreatment of the donors with oestrogen and it was suggested that such a substance may be involved in inhibiting blastocyst metabolism in delayed implantation by preventing transcription of genetic information.

Other arguments brought forward in support of a uterine inhibitor are that embryos in extra-uterine locations in 'delayed implanting' animals are active and develop even though blastocysts in the uterine horns of the same animals are dormant. As McLaren (1973) points out, such activity could be due to removal of a uterine inhibitor, but it is equally reasonable to suppose that serum or cellular exudates in the extra-uterine site are stimulatory. If a uterine inhibitor is responsible for the dormant condition of the embryos in delayed implantation, it must be rapidly neuiralized or removed by oestrogen in the presence of progesterone.

The fact that protein synthesis and $\mathrm{CO}_{2}$ production by 'delayed implanting' embryos increases in vitro in a relatively simple medium is compatible with both possibilities. However, the medium used in the protein synthesis and $\mathrm{CO}_{2}$ experiments discussed above does not contain serum or serum fractions and the only macromolecular constituent is crystalline bovine albumin. Bovine albumin does not exert a stimulatory effect since the normal embryos do not show increased metabolism. Although the argument that albumin specifically stimulates 'delayed implanting' embryos cannot be excluded, it seems more likely that the embryos 'escape' from an inhibitory influence of the uterus with increasing time in vitro.

The next logical experimental steps involve the testing of uterine fluid from normal and 'delayed implanting' mice to determine whether or not it influences embryonic metabolism in vitro. For example, if an inhibitor is involved in delayed implantation, one might expect uterine fluid from ovariectomized, progesterone-treated mice to reduce $\mathrm{CO}_{2}$ production and protein synthesis by normal blastocysts and to prevent the increase in metabolism of 'delayed implanting' embryos in vitro. If, on the other hand, a stimulatory substance is involved in activating embryos at the time of implantation, uterine fluid from intact or oestrogen and progesterone-treated animals might be expected to shorten the time necessary to develop increased $\mathrm{CO}_{2}$ production and protein synthesis by 'delayed implanting' embryos in vitro.

In either case, the solution of this problem will provide clues to the method by which the maternal and fetal organisms communicate before nidation and thus improve our understanding of the mechanisms controlling implantation.

\section{ACKNOWLEDGMENTS}

This work was supported by grants from the AEC (Report COO-1801-30), the Ford Foundation and a travel grant from the NSF (BG-39361). 


\section{REFERENGES}

BRINster, R. L. (1967a) Carbon dioxide production from glucose by the preimplantation mouse embryo. Expl Cell Res. 47, 271.

Brinster, R. L. (1967b) Protein content of the mouse embryo during the first five days of development. 7. Reprod. Fert. 13, 413.

BRINSTER, R. L. (1969) Incorporation of carbon from glucose and pyruvate into the preimplantation mouse embryos. Expl Cell Res. 58, 153.

BRINSTER, R. L. (1971) Uptake and incorporation of amino acids by the preimplantation mouse embryo. F. Reprod. Fert. 27, 329.

Brinster, R. L. \& Thomson, J. L. (1966) Development of eight-cell mouse embryos in vitro. Expl Cell Res. 42, 308.

GLAss, L. E. \& Hanson, J. E. (1969) Uptake of protein precursors by mouse embryos in vitro. Anat. Rec. 163,303 .

Graves, G. N. \& Biggers, J. D. (1970) Carbon dioxide fixation by mouse embryos prior to implantation. Science, N.Y. 167, 1506.

Greenwald, G. S. \& Everett, N. B. (1959) The incorporation of $\mathrm{S}^{35}$ methionine by the uterus and ova of the mouse. Anat. Rec. 134, 171.

Gulyas, B. J. \& Daniel, J. C., JR (1969) Incorporation of labeled nucleic acid and protein precursors by diapausing and non-diapausing blastocysts. Biol. Reprod. 1, 11.

Gwatkin, R. B. L. (1966) Amino acid requirements for attachment and outgrowth of the mouse blastocyst in vitro. $\mathbf{7}$. cell. Physiol. 68, 335.

Gwatkin, R. B. L. (1969) Nutritional requirements for post-blastocyst development in the mouse. Amino acids and protein in the uterus during implantation. Int. F. Fert. 14, 101.

Hsu, Y. G. (1972) Differentiation in vitro of mouse embryos beyond the implantation stage. Nature, Lond. 239, 200.

Hsu, Y. C. \& Baskar, J. (1973) Differentiation in vitro of mouse embryo from two-cell egg to early somite. Fedn Proc. Fedn Am. Socs exp. Biol. 32, 254 (No. 235).

Kirby, D. R. S. (1969) The extra-uterine mouse egg as an experimental model. Adv. Biosci. 4, 253.

KRAMEN, M. A. \& BIGGERs, J. D. (1971) Uptake of tricarboxylic acid cycle intermediates by preimplantation mouse embryos in vitro. Proc. natn. Acad. Sci. U.S.A. 68, 2656.

Lowry, O. H., Rosebrough, N. J., FarR, A. L. \& Randall, R. J. (1951) Protein measurement with the Folin phenol reagent. F. biol. Chem. 193, 265.

McLaren, A. (1973) Blastocyst activation. In The Regulation of Mammalian Reproduction, p. 321. Eds. S. J. Segal, R. Grozier, P. A. Gorfman and P. G. Gondliffe. Charles G. Thomas, Springfield, Illinois.

Menke, T. M. (1972) Changes in mouse blastocyst carbon dioxide production as a function of time postcoitum in delay of implantation during lactation or following ovariectomy. Biol. Reprod. 7, 414.

Menke, T. M. \& Mclaren, A. (1970a) Mouse blastocysts grown in vivo and in vitro: carbon dioxide production and trophoblast outgrowth. F. Reprod. Fert. 23, 117.

Menke, T. M. \& McLaren, A. (1970b) Carbon dioxide production by mouse blastocysts during lactational delay of implantation or after ovariectomy. F. Endocr. 47, 287.

Mills, R. M., JR \& BRINSTER, R. L. (1967) Oxygen consumption of preimplantation mouse embryos. Expl Cell Res. 47, 337.

MinTz, B. (1964) Synthetic processes and early development in the mammalian egg. F. exp. Zool. 157, 85.

Mintz, B. (1965) Nucleic acid and protein synthesis in the developing mouse embryo. In Preimplantation Stages of Pregnancy, p. 145. Eds. G. E. W. Wolstenholme and M. O'Gonnor. Little, Brown and Company, Boston.

Monesi, V., Molinaro, M., Spalletta, E. \& Davoli, G. (1970) Effect of metabolic inhibitors on macromolecular synthesis and early development in the mouse embryo. Expl Cell Res. 59, 197.

Monesi, V. \& SALFI, V. (1967) Macromolecular synthesis during early development in the mouse embryo. Expl Cell Res. 46, 632.

Prasad, M. R. N., Dass, G. M. S. \& Mohla, S. (1968) Action of oestrogen on the blastocyst and uterus in delayed implantations-an autoradiographic study. F. Reprod. Fert. 16, 97.

Psychoyos, A. \& Brtton-Casimiri, V. (1969) Captation in vitro d'un précurseur d'acide ribonucléique (ARN) (uridine- $5-{ }^{3} \mathrm{H}$ ) par le blastocyste du rat; différences entre blastocystes normaux et blastocystes en diapause. C. r. hebd. Séanc. Acad. Sci., Paris, 268, 188.

SмrтH, D. M. \& Sмтrн, A. E. S. (1971) Uptake and incorporation of amino acids by cultured mouse embryos: estrogen stimulation. Biol. Reprod. 4, 66.

TAsCa, R. J. \& Hillman, N. (1970) Effects of actinomycin D aid cycloheximide on RNA and protein synthesis in cleavage stage mouse embryos. Nature, Lond. 225, 1022. 
Thomson, J. L. \& Biggers, J. D. (1966) Effect of inhibitors of protein synthesis on the development of preimplantation mouse embryos. Expl Cell Res. 41, 411 .

Torbit, C. A. \& WeItLAUF, H. M. (1974) The effect of oestrogen and progesterone on $\mathrm{CO}_{2}$ production by delayed implanting mouse embryos. $\mathcal{F}$ Reprod. Fert. 39, 379.

Tsujir, H., Sugawara, S. \& Takeughi, S. (1972) Effect of estrone on incorporation of ${ }^{14}$ G-glutamic acid in rat blastocyst during delayed implantation. Fap. F. zootech. Sci. 43, 660 .

WALEs, R. G. \& BRINSTER, R. L. (1968) The uptake of hexoses by pre-implantation mouse embryos in vitro. F. Reprod. Fert. 15, 415.

Wales, R. G., Quinn, P. \& MURDoch, R. N. (1969) The fixation of carbon dioxide by the eight-cell mouse embryo. F. Reprod. Fert. 20, 541.

Weitr.auf, H. M. (1969) Temporal changes in protein synthesis by mouse blastocysts transferred to ovariectomized recipients. F. exp. Zool. 171, 481.

Wertlauf, H. M. (1971) Protein synthesis by blastocysts in the uteri and oviducts of intact and hypophysectomized mice. F. exp. Zool. 176, 35 .

WeITLAUF, H. M. (1973a) In vitro uptake and incorporation of amino acids by blastocysts from intact and ovariectomized mice. F. exp. Zool. 183, 303.

Weitlaup, H. M. (1973b) Changes in the protein content of blastocysts from normal and delayed implanting mice. Anat. Rec. 176, 121.

WeitLauf, H. M. \& GreEnWALd, G. S. (1965) A comparison of ${ }^{35} \mathrm{~S}$ methionine incorporation by the blastocysts of normal and delayed implanting mice. F. Reprod. Fert. 10, 203.

Wertlaur, H. M. \& GReENwald, G. S. (1967) A comparison of the in vivo incorporation of $\mathrm{S}^{35}$ methionine by two-celled mouse eggs and blastocysts. Anat. Rec. 159, 249.

WeITLAUP, H. M. \& GREENWALD, G. S. (1968) Influence of estrogen and progesterone on the incorporation of ${ }^{35} \mathrm{~S}$ methionine by blastocysts in ovariectomized mice. F. exp. Zool. 169, 463.

WhItTEN, W. K. (1955) Endocrine studies on delayed implantation in lactating mice. F. Endocr. 13, 1.

Whrrten, W. K. (1958) Endocrine studies on delayed implantation in lactating mice. Role of the pituitary in implantation. $\mathcal{F}$. Endocr. 16, 435 . 